\title{
TEORIA dA DIVISÃo DINÂMICA DO ÔNUS DA PROVA COMO FORMA DE ATENDIMENTO DO ACESSO À JUSTIÇA
}

\author{
Theory of dynamic division of burden of proof of service as a means of \\ access to justice
}

\section{Aline Aparecida Santos Costa}

Possui graduação em Direito pelo Centro Universitário das Faculdades Metropolitanas Unidas e Pós-graduanda em Direito Civil e Processo Civil pela Faculdade Escola Paulista de Direito. E-mail: aline@peghini.com.br.

\section{Cesar Calo Peghini}

Doutorando em Direito pela PUC/SP. Possui graduação em Direito pelo Centro Universitário das Faculdades Metropolitanas Unidas, Curso de Extensão em Direito Imobiliário pela Faculdade Autônoma de Direito - Fadisp, Pós-graduado em Direito Civil e Processo Civil pela Faculdade Escola Paulista de Direito, Pós-graduado (LLM) em Direito Civil pela Instituição Toledo de Ensino e Mestrado pela Faculdade Autônoma de Direito - Fadisp. Professor do curso de graduação em Direito da FMU.E-mail: cesar@peghini.com.br.

RECEBIDO EM: 02.02.2013

APROVADO EM: 01.05.2013

“Nenhuma regra é tão geral que não admita alguma exceção”. Robert Burton.

\section{RESUMO}

Diante da moderna concepção jurídica em tornar o direito cada vez mais acessível aos indivíduos e, frente a crescente vertente entre os doutrinadores contemporâneos em constitucionalizar as normas, podemos observar a possibilidade da implementação de uma nova dinâmica quanto ao ônus da prova. O presente artigo pretende analisar os novos, os velhos conteúdos e contextos comprobatórios frente à instauração de um processo e a possibilidade da aplicação por ofício pelo magistrado da inversão do ônus, naquilo que a parte impetrante embora alegue, não tenha condição de fazê-la, senão pela parte adversa, sem deixar de observar os ditamente Principiológicos Constitucionais, em especial o Acesso à Justiça. 
Palavras-Chave: Acesso à justiça. Instrução probatória. Provas. Distribuição diNÂMICA DO ÔNUS DA PROVA.

\begin{abstract}
Given the modern legal thinking in making the right increasingly accessible to individuals, and, before growing strand among contemporary scholars in constitutionalize the rules, we can see the possibility of implementing a new dynamic as the burden of proof. This monograph seeks to analyze the new and the old contents and contexts evidentiary forward the establishment of a process and the possibility of the application by letter by the magistrate of the reversal of the burden, what part though plaintiff alleges, did not make her condition, but by the opposing party, while observing the dictates Principiológicos Constitutional, particularly access to justice.
\end{abstract}

Keywords: Access to justice. Instruction evidential. Evidence. Dynamic distribuTION OF THE BURDEN OF PROOF.

SUMÁRIO: Introdução. 1. Noções gerais sobre a instrumentalização das normas e o estado. 1.1. Noções gerais. 1.2. Processo e deliberações iniciais do magistrado e sua jurisdição. 1.3. Sujeitos da relação processual. 2. Da prova elementos e características existenciais. 2.1. Noções gerais e conceito de prova. 2.2. Características das provas. 2.3. Meios de provas. 3. Poderes instrutórios do juiz. 3.1. Atuação do juiz dentro do processo civil. 3.2. limites do poder de instrução. 4. Teoria da divisão dinâmica do ônus da prova. 4.1. Fontes de provas. 4.2. Ônus da prova acepção geral. 4.3. Teoria da divisão dinâmica do ônus da prova como forma de atendimento do acesso à justiça. Conclusão. Referências.

\title{
INTRODUÇ̃̃o
}

Atribui o inciso LV, artigo $5^{\circ}$ da Carta Magna a possibilidade do gozo dos elementos mais consagrados do Direito Processual, trata-se do princípio do contraditório e o princípio da ampla defesa, cuja principal finalidade é conceder às partes a possibilidade de interpor todas as provas necessárias e admitidas em direito, e ainda, se valer de todas as instâncias em busca de suas pretensões.

O presente artigo analisará o poder instrutório do juiz, e ainda, verificará em paralelo o artigo 333 do Código de Processo Civil que trata da incumbência quanto ao ônus da prova. 
Em regra as provas são avaliadas e tomadas na fase instrução, se eventualmente uma das partes seja "hipossuficiente" em relação ao seu direito probatório, diante de carecer meios em obtê-las, questiona-se: o juiz ao pesar o artigo 333, CPC, teria condições de agir rumo à verdade real, mesmo contrariando entendimento do artigo supra? Como ficaria o direito de defesa e o contraditório? Há ferimento de princípios basilares?

Do exposto, este será o objeto pontuado no presente trabalho, pois é imprescindível que as partes possam se valer do acesso à justiça para o fim de resolver uma lide e, os magistrados não se sintam presos em buscar a verdade real dos fatos pretéritos, mas sim, se valham rumo à busca da justiça para responder a clemência da sociedade em ter um Estado justo.

Ressalta-se que o presente artigo realiza corte metodológico proposto nos termos da temática supracitada, bem como utiliza como critério pesquisa o método indutivo e dedutivo de pesquisa científica ${ }^{1}$.

\section{NoÇões Gerais SObre a InSTRUMentalizaÇão das nORMAS E O Estado}

\subsection{NoÇÕES GERAIS}

Diante da vida social presenciada pelo ser humano, verifica-se a necessidade em normatizar o seu comportamento. Assim, com o avançar dos tempos houve a implementação de um conjunto de normas, em constante evolução, com direitos e deveres que visam regularizar a vida em comum.

Uma forma de instrumentalizar estas vias refere à aplicação do Direito Processual, pois dá forma de atuação do direito material, frente ao conflito estabelecido entre as partes que pretendem satisfazer suas pretensões.

Para Fernando da Costa Tourinho Filho ${ }^{2}$ o "homem deve viver em sociedade” assim, é cabível a uma coletividade de pessoas, a sociedade, uma organização para o fim de obter o bem estar social.

Cabe ao Poder Soberano do Estado estabelecer restrições, direitos e deveres para limitar uma liberdade incondicionada ao indivíduo, à liberdade do outro.

Neste contexto trata Arruda Alvim³:

A resistência à pretensão, obstando a submissão do interesse de um ao do outro, gera conflito de interesses. Esse conflito de interesses, ocorrido na

\footnotetext{
${ }^{1}$ Mais sobre o sistema de pesquisa leia: GUSTIN, Miracy Barbosa de Sousa. (RE) pensando a pesquisa jurídica. Belo Horizonte: Del Rey, 2006.

${ }^{2}$ TOURINHO FILHO, Fernando da Costa. Manual de Processo Penal. Ed. Saraiva. 1997. p. 01 .

${ }^{3}$ ALVIM, Arruda. Manual de Direito Processual Civil. 13. ed. São Paulo: Revista dos Tribunais. 2010. p. 39 .
} 
vida social, é, através do pedido do autor, feito ao Estado-juiz, transladado da vida social, enquadrado num esquema jurídico e colocado diante de uma autoridade imparcial, o juiz, que até este momento o ignorava.

Assim, é concedido ao Estado, por meio de normas e princípios o poderdever de regularizar a vida em comum, seja ao impor suas normas, seja ao regularizar os elementos essenciais para subsistência do povo, território e do governo.

Nesse ínterim o Estado se vale os Poderes Legislativo, Executivo e Judiciário, estes distintos em suas funções, mas unidos pela mesma finalidade: a obtenção da paz social e a organização da sociedade. ${ }^{4}$

Assim é pela atuação normativa do Legislativo, que as leis são elaboradas; pela gestão administrativa do Executivo, as leis ganham vida e dinâmica; pela intervenção jurisdicional dos órgãos do Judiciário, elas obtêm garantia e salvaguarda, abandonando o terreno da normatividade abstrata para alcançar o solo tormentoso das divergências e disputas concretas 5 .

Do exposto atenta-se a importância da figura do Estado, pois este surge para viabilizar a resolução do conflito entre as partes litigantes a fim de reafirmar sob pena de sanção, que a lei e seus procedimentos devem ser tidos além de um remédio para a harmonia social, mas preponderantemente para regrar o convívio mínimo entre aqueles que se submetem a elas.

Há três modos para a composição desses litígios. Os indivíduos podem se valer da autocomposição, que nada mais é do que os litigantes se comporem amigavelmente, sem a necessidade de buscar o apoio do Poder Judiciário para solução da disputa. Poderão, ainda, buscar a ajuda de um terceiro estranho ao litígio para resolver o conflito. E, por fim, poderão recorrer a um órgão do Estado, com o propósito de verem sanada esta demanda através do julgamento de um juiz ou tribunal ${ }^{6}$.

Ante ao tema, se faz salutar algumas linhas sobre a importância do Acesso à justiça.

Discorrem Cappelletti e Garth7 sobre a expressão "Acesso à justiça”, neste contexto, é compreendida de um meio pelo qual os indivíduos podem se valer do Estado, com a finalidade de reivindicar seus direitos e deveres, bem como resolver suas pretensões resistidas.

Nesse sentido importante ressalta o artigo $5^{\circ}$, LIV da Constituição Federal:

\footnotetext{
${ }^{4}$ ALVIM, Arruda. Manual de Direito Processual Civil. 13. ed. São Paulo: Revista dos Tribunais. 2010. p. 60.

${ }^{5}$ LENZA, Pedro e GONÇALVES, Marcus Vinicius Rios. Direito Processual Civil esquematizado. 3. ed. São Paulo: Saraiva, 2012. p. 88.

${ }^{6}$ NEVES, Daniel Amorim Assumpção. Manual de Direito Processual Civil. 3. ed. São Paulo: Método. 2011. p. 51 e seguintes.

${ }^{7}$ Acesso à Justiça. Disponível em: http://xa.yimg.com/kq/groups/24783186/788476264/name/2-+Maur. Acessado em: 02.07.2013.
} 
ninguém será privado da liberdade ou de seus bens sem o devido processo legal. Sem sobra de dúvidas trata da conquista da edição da Carta Magna, por João Sem Terra, no século XIII. ${ }^{8}$

Assim, o Estado em contrapartida deve ser acessível aos seus interessados e ainda deverá produzir uma solução tempestiva a uma justiça social que foi demandada ${ }^{9}$.

Para tanto, os direitos individuais receberam com a Constituição Federal de 1988, uma amplitude em sua obtenção, ou seja, a vigente Carta Magna diminuiu a distância que havia entre o povo e a justiça conforme muito bem apontam Cintra, Grinover e Dinamarco ${ }^{10}$.

Em conformidade, assevera o artigo $5^{\circ}, \mathrm{XXXV}$, da CF:

Art. $5^{\circ}$ - Todos são iguais perante a lei, sem distinção de qualquer natureza, garantindo-se aos brasileiros e aos estrangeiros residentes no País a inviolabilidade do direito à vida, à liberdade, à igualdade, à segurança e à propriedade, nos termos seguintes: [...] XXXV - a lei não excluirá da apreciação do Poder Judiciário lesão ou ameaça a direito.

O conteúdo discorrido acima trata de um princípio de suma importância ao qual concede a todos os interessados, sejam brasileiros natos ou naturalizados, indistintamente, a possibilidade de se valerem do judiciário ${ }^{11}$ e também pelos meios de resolução de conflitos como o uso da arbitragem, mediação e conciliação ${ }^{12}$.

O elemento principiológico, visa garantir ao indivíduo lesionado ou, na ameaça de sofrer restrições em seu direito ${ }^{13}$, garantias constitucionais em acionar o Poder Judiciário e de ter para si o amparo Estatal.

O amparo Estatal se dá pela impossibilidade da parte "lesionada" arcar com os custos da demanda em face ao seu ofensor, com as taxas judiciárias, e despe-

${ }^{8}$ Nesse sentido: LENZA, Pedro e GONÇALVES, Marcus Vinicius Rios. Direito Processual Civil esquematizado. 3. ed. São Paulo: Saraiva, 2012. p.60. MACHADO, Costa. Código de Processo Civil interpretado e anotado. São Paulo: Manole. 2006. p 19.

${ }^{9}$ MACHADO, Costa. Código de Processo Civil interpretado e anotado. São Paulo: Manole. 2006. p. 19.

${ }^{10}$ Nesse sentido: CINTRA, Antonio Carlos de Araújo. GRINOVER, Ada Pellegrini Grinover. DINAMARCO, Cândico R. Teoria Geral do Processo. 9. ed. São Paulo: Malheiros. 1993. p. 75. BERMUDES, Sergio. Direito Processual Civil. Estudos e pareceres. 2a série. São Paulo: Saraiva. 1994. p.7.

${ }^{11}$ Nesse sentido: MACHADO, Costa. Código de Processo Civil interpretado e anotado. São Paulo: Manole. 2006. p. 11.

12 LENZA, Pedro e GONÇALVES, Marcus Vinicius Rios. Direito Processual Civil esquematizado. 3. ed. São Paulo: Saraiva, 2012. p. 61.

${ }^{13}$ Acesso à Justiça. Disponível em: http://www.jurisway.org.br/v2/dhall.asp?id_dh=5182. Acessado em: 02.07.2013. 
sa com honorários advocatícios ${ }^{14}$.

Frente à prestação jurisdicional que era para poucos, devido ao elevado custo de um processo rumo a solução definitiva de uma lide, o acesso à Justiça na atualidade é realizada pelas Defensorias Públicas Estaduais, as quais perante o artigo $134^{15}$, da Carta Magna, têm a função de orientar e defender os indivíduos que dela necessitarem.

Isso porque, o auxílio de um advogado é indispensável para compreender as leis e para demandar uma ação, assim sabiamente adotou o Estado uma atitude positiva em garanti-la ${ }^{16}$.

Em consonância o artigo $5^{\circ}$, inciso LXXIV, da Constituição Federal, traz a seguinte redação: "O Estado prestará assistência jurídica integral e gratuita aos que comprovarem insuficiência de recursos".

Não obstante, o legislador fez a previsão apresentada pela Emenda Constitucional $n^{\circ} 45$, de 8/12/2004, que trata da celeridade processual. Ou seja, de nada adiantaria impetrar uma demanda, se o Poder Judiciário não garantisse à ação, uma decisão tempestiva, com uma razoável duração.

Assim, o artigo 5", LXXVIII, CF dispõe "a todos, no âmbito judicial e administrativo, são assegurados a razoável duração do processo e os meios que garantam a celeridade de sua tramitação."

O inciso acima, corrobora o sentimento e anseio da sociedade carente de um Poder Público ágil e comprometido com a realização digna e lídima de um pro$\operatorname{cesso}^{17}$.

Ainda, pretende ressaltar a possibilidade e grandes grupos se valerem do Poder Judiciário para representarem o direito difuso ${ }^{18}$, estes antes tão cerceados em seus propósitos, neste sentido tratam Cappelletti e Garth:

[...] a proteção de tais interesses tornou necessária uma transformação do papel do juiz e de conceitos básicos como a "citação" e o "direito de ser ouvido". Uma vez que nem todos os titulares de um direito difuso podem comparecer em juízo - por exemplo, todos os interessados na manutenção

\footnotetext{
${ }^{14}$ LENZA, Pedro e GONÇALVES, Marcus Vinicius Rios. Direito Processual Civil esquematizado. 3. ed. São Paulo: Saraiva, 2012. p.187.

15 “Art. 134. A Defensoria Pública é instituição essencial à função jurisdicional do Estado, incumbindo-lhe a orientação jurídica e a defesa, em todos os graus, dos necessitados, na forma do artigo $5^{\circ}$, LXXIV".

${ }^{16}$ Acesso à justiça. Disponível em: http://xa.yimg.com/kq/groups/24783186/788476264/name/2-+Maur . Acessado em: 02.07.2013.

${ }^{17}$ MACHADO, Costa. Código de Processo Civil interpretado e anotado. São Paulo: Manole. 2006. p. 48.

${ }^{18}$ Acesso à justiça. Disponível em: http://xa.yimg.com/kq/groups/24783186/788476264/name/2-+Maur. Acessado em: 02.07.2013.
} 
da qualidade do ar, numa determinada região - é preciso que haja um "representante adequado" para agir em benefício da coletividade , mesmo que os membros dela não sejam "citados" individualmente.

Do exposto, verifica-se que vulnerabilidade da sociedade em ver sua pretensão ouvida e resolvida pelo Estado. Assim, a importância e relevância desta abordagem quanto da possibilidade em acessar a justiça tempestivamente e da viabilidade em ser solucionada de forma a abarcar a lídima tramitação processo em resposta ao anseio social.

\subsection{Processo e Deliberações iniciais do magistrado e SUa JURisdição}

Em sentido amplo, verifica-se que o processo é um ato de proceder; é a maneira de operar, conjunto de papéis relativos a um negócio ${ }^{19}$. Todavia, derivado do "pro cedere", que nada mais é que ir para frente, fazer progresso, prosperar, no sentido de se buscar a solução de um litígio.

Com o ensinamento Tourinho Filho ${ }^{20}$, aprende-se que:

É por meio de processo que se compõem os litígios. O processo consiste, assim, numa sucessão de atos que culminam com a decisão final do órgão jurisdicional pondo fim ao litígio, dando a cada um o que é seu.

Ao magistrado é dada a incumbência de engatilhar a marcha processual e assim desenvolvê-la com os atos das partes e dos auxiliares de justiça ${ }^{21}$.

Sendo assim, parece cristalina a ideia de que o procedimento está fundamentalmente aliado ao processo, pois, para que o magistrado possa atuar, e assim cumprir o mandamento legal, é indispensável que se manifeste deliberando atos para regular andamento do feito, a fim de dar cumprimento à norma com o intuito único de pôr um ponto final na lide.

Neste sentido, José Antonio Pimenta Bueno ${ }^{22}$ :

Quando atos se coordenam numa série sucessiva com um fim determinado, fala-se que há processo, se o movimento se realiza em função da ativida-

\footnotetext{
19 Jornal da tarde. Dicionário Brasileiro da Língua Portuguesa. Porto Alegre: Ed. Globo. 1994.

${ }^{20}$ TOURINHO FILHO, Fernando da Costa. Manual de Processo Penal. Ed. Saraiva. 1997. p. 11 .

${ }^{21}$ CÂMARA, Alexandre Freitas. Lições de direito processual civil. 24. ed. São Paulo: Ed. Atlas. 2013. p.55.

22 BUENO, José Antonio Pimenta. Apontamentos sobre o Processo Criminal Brasileiro. $3^{\mathrm{a}}$. ed. Rio de Janeiro: H. Ganier, 1959. p. 23.
} 
de jurisdicional; se for uma atividade administrativa que se desenvolve, o que existe nesta série de atos que se entrelaçam é tão só procedimento. $\mathrm{O}$ procedimento é o conteúdo formal do processo, do mesmo modo que a lide é o seu conteúdo material ou substancial. O processo é a atividade jurisdicional na sua função de aplicar a lei; o procedimento de "modus faciendi" com que essa atividade se realiza.

Em suma, o processo se inicia com a propositura da ação, e se encerra depois de percorrido todo o procedimento processual, com a entrega da prestação jurisdicional invocada, ditada pelo magistrado e que resume o direito pertinente a cada uma das partes.

\subsection{Sujeitos da Relação Processual}

Aduz Tourinho Filho ${ }^{23}$ que os sujeitos processuais são todas as pessoas que atuam no processo, ou seja: juiz, partes, auxiliares de justiça, testemunhas etc.

Para haver uma relação jurídica é indispensável que exista uma relação intersubjetiva, um vínculo entre duas ou mais partes, previstas pela norma, quais sejam: Autor, Estado-juiz e Réu ${ }^{24}$.

Fala-se ainda, que as partes se distinguem em partes materiais e partes processuais. No primeiro grupo são os sujeitos da relação, isto é, em sujeito ativo e sujeito passivo; no segundo, a posição processual que cada um desses sujeitos ocupa, a saber, parte Autora e parte Ré ${ }^{25}$.

No mais, não é factível deixar de tratar as relações jurídicas que comportam mais de três sujeitos processuais. E isso se dá, particularmente, nos casos de litisconsórcio, passivo ou ativo, nos quais se constata o fenômeno da ampliação subjetiva do litígio ${ }^{26}$.

Portanto, ao Estado-juiz, além da incumbência de solucionar o litígio, claro que visto de uma forma equidistante, cabe qualificar juridicamente as relações sociais de conformidade com o modelo normativo que é empregado no caso prático em tela ${ }^{27}$.

Feitas as referidas anotações passa a estudar o elemento fundamental da presente pesquisa, ou seja, a prova e suas características.

${ }^{23}$ TOURINHO FILHO, Fernando da Costa. Manual de Processo Penal, p. 331.

${ }^{24}$ MONTENEGRO FILHO, Misael. Código de Processo Civil comentado e interpretado. 3. ed. São Paulo: Atlas. 2013. p.31.

${ }^{25}$ NERY JUNIOR, Nelson e ANDRADE NERY, Rosa Maria de. Código de Processo Civil Comentado e Legislação extravagante. 9. ed. São Paulo: Revista dos Tribunais, 2006. p.160.

${ }^{26}$ NEVES, Daniel Amorim Assumpção. Manual de Direito Processual Civil. 3. ed. São Paulo: Método. 2011. p.181.

${ }^{27}$ LENZA, Pedro e GONÇALVES, Marcus Vinicius Rios. Direito Processual Civil esquematizado. 3. ed. São Paulo: Saraiva, 2012. p. 183. 


\section{DA PROVA ELEMENTOS E CARACTERÍSTICAS EXISTENCIAIS}

\subsection{NOÇÕES GERAIS E CONCEITO DE PROVA}

Para instrumentalizar uma pretensão o Autor no processo-demanda deve munir sua inicial com as mais variadas formar de se demonstrar o seu direito, assim, este tema é de suma importância e deve ser tratado com toda sutileza ${ }^{28}$.

A priori cumpri transcrever, que recai ao magistrado a convicção e a busca da verdade dos fatos alegados no direito que se pretende obter, bem como a possibilidade jurídica do direito, posto isso, as provas servirão para formação de suas convicções e o poder dizer o direito ${ }^{29}$.

O objetivo essencial da prova é a resolução de um fato controverso, ou seja, uma das partes asseveram de uma forma e a parte adversa dá uma interpretação diversa $^{30}$.

A transcrição concisa dos fatos dará ao magistrado condições de analisar o caso concreto e julgar o litígio em sentença a ser prolatada ${ }^{31}$.

Para Humberto Theodoro Júnior ${ }^{32}$ existem duas formas de se conceituar a produção de provas, seja pelo elemento objetivo, seja pelo subjetivo.

a) um objetivo, isto é, como o instrumento ou o meio hábil, para demonstrar a existência de um fato (os documentos, as testemunhas, a perícia, etc.); b) e outro subjetivo, que é a certeza (estado psíquico) originada quanto ao fato, em virtude da produção do instrumento probatório. Aparece a prova, assim, como convicção formada no espírito do julgador em torno do fato demonstrado.

Portanto, uma pretende expor a existência do fato - objetiva e a outra trata

\footnotetext{
${ }^{28}$ MOREIRA, José Carlos Barbosa. O novo processo civil Brasileiro. 8. ed. Rio de Janeiro: Forense. 2010. p. 3.

${ }^{29}$ Nesse sentido: SANTOS, Moacyr Amaral. Primeiras linhas de direito Processual Civil. $2^{\circ}$ vol. 22. ed. São Paulo: Saraiva. 2002. p. 349. RENHART, Sérgio C., MARINONI, Luiz Guilherme. Comentários ao Código de Processo Civil. $5^{\circ}$ vol. Tomo I. Ed. São Paulo: Revista dos Tribunais, 2000. p. 35.

${ }^{30}$ MONTENEGRO FILHO, Misael. Código de processo civil comentado e interpretado.3. ed. São Paulo: Atlas. 2013. p. 402.

${ }^{31}$ BUENO, Cassio Scarpinella. Curso sistematizado de direito processual civil. Teoria geral do direito processual civil. 4. ed. São Paulo: Saraiva. 2010. p. 440.

${ }^{32}$ Nesse sentido: THEODORO JÚNIOR, Humberto. Curso de Direito Processual Civil Teoria geral do direito processual civil e processo de conhecimento. Vol. I. Rio de Janeiro: Forense, 2012.P.437. SANTOS, Moacyr Amaral. Primeiras linhas de direito Processual Civil. $2^{\circ}$ vol. 22. ed. São Paulo: Saraiva. 2002. p. 335.
} 
da forma subjetiva -, que é a própria convicção do indivíduo ${ }^{33}$.

Em latim, proba, de probare consiste em reconhecer, formar juizo, demonstrar, ou seja, é o significado da prova ${ }^{34}$.

No âmbito jurídico, provar é o meio pelo qual se demonstra a existência, a veracidade de um ato ou fato. Neste passo assevera oportunamente Humberto Theodoro Júnior ${ }^{35}$ que diante da história jurídica da humanidade, apenas neste século foi possível obter uma configuração constitucional de direitos fundamentais.

Para Luiz Marinoni e Sérgio Arenhart ${ }^{36}$ apud Marco Antônio Rebouças da Costa $^{37}$ reconhecido por parte da doutrina que a pretensão para se obter a verdade real em atos/fatos vivenciados no passado não passa de uma utopia, pois entendem que a fase probatória no processo não é capaz de restituí-la pelos meios de prova, seja pericial, oitiva de testemunhas, seja documental etc.

Tal entendimento vai ao encontro dos ensinamentos já apontados neste trabalho por Humberto Teodoro Junior, pois, na reconstrução da situação presenciada pelas partes, os fatos, receberão uma carga de subjetivismo pelos que nela presenciaram.

Nesta senda, é passível compreender que na fase comprobatória, busca-se o maior argumento possível para que o magistrado possa se valer de um juízo verossímil dentro de uma realidade que se buscou reconstruir atos/fatos pretéritos ${ }^{38}$.

Provar, na matéria de Processo Civil, implica dizer que a atividade desenvolvida pelas partes no processo, destina-se trazer aos autos, informações que demonstrem a veracidade das suas alegações ${ }^{39}$.

Contudo, há doutrinadores que entendem que a arte de provar vai muito além, ou seja, além da subjetividade já tratada, pela parte que a produziu em demonstrar sua pretensão, a compreensão da sua extensão caberá ao magistrado em

${ }^{33}$ NERY JUNIOR, Nelson e ANDRADE NERY, Rosa Maria de. Código de Processo Civil Comentado e Legislação extravagante. 9. ed. São Paulo: Revista dos Tribunais, 2006 .p. 527.

${ }^{34}$ Jornal da tarde. Dicionário Brasileiro da Língua Portuguesa. Porto Alegre: Ed. Globo. 1994.

${ }^{35}$ THEODORO JÚNIOR, Humberto. Curso de Direito Processual Civil - Teoria geral do direito processual civil e processo de conhecimento. Vol. I. Rio de Janeiro: Forense, 2012. RENHART, Sérgio C., MARINONI, Luiz Guilherme. Comentários ao Código de Processo Civil. $5^{\circ}$ vol. Tomo I. Ed. São Paulo: Revista dos Tribunais, 2000. p. 25.

${ }^{36}$ ARENHART, Sérgio C., MARINONI, Luiz Guilherme. Teoria Geral do Processo. 3. ed. Rev e atual. - São Paulo: Editora Revista dos Tribunais, 2008.p. 281.

${ }^{37}$ COSTA, Marco Antônio Rebouças da. Considerações Sobre a Prova no Processo Civil. Acessado em: 11.07.2013. Disponível em: http://jus.com.br/revista/texto/11358/consideracoes-sobre-a-prova-no-processo-civil.

${ }^{38}$ ALVIM, Arruda, ASSIS, Araken e ALVIM, Eduardo Arruda. Comentários ao Código de Processo Civil.Rio de Janeiro: G/Z Editora. 2012. p. 516.

${ }^{39}$ RENHART, Sérgio C., MARINONI, Luiz Guilherme. Comentários ao Código de Processo Civil. $5^{\circ}$ vol. Tomo I. Ed. São Paulo: Revista dos Tribunais, 2000.p. 30. 
traduzi-la, pois este se serve dos documentos, dos apontamentos feitos pela perícia por exemplo, e da sua percepção quanto da lógica/percepção e dedução que resultam da sua lógica do conhecimento ${ }^{40}$.

Portanto, quanto ao conceito da prova tem-se o aspecto da perspectiva objetiva, ou seja, instrumentalizar o sentido das afirmações para conhecimento das partes e do magistrado, ou seja, o aspecto subjetivo em demonstrar ao magistrado a alegação presente, ao conhecimento geral, dos adventos pretéritos, assumindo então uma função dialética e dialógica.

\subsection{Características das provas}

De acordo com o objeto a prova pode ser diferenciada em diretas e indiretas. As diretas perfazem devido à relação imediata com o fato, ou seja, ela tem uma relação direta do objeto controverso, diferentemente se entende pela prova indireta, pois embora não esteja ligada diretamente ao fato/ato, diante de um raciocínio lógico pode se depreender ligação com a matéria tida como necessária para provar, portanto, mais complexa ${ }^{41}$.

Já quanto há necessidade de perícia, por exemplo, é necessário que o magistrado seja levado a crer na relação jurídica que se pretende provar por meio dos indícios relatados.

Existem diversas formas de levar a convicção ao magistrado da pretensão do bem jurídico que se pretende obter ou proteger, podendo ser: a) pessoal: declarações, depoimentos e testemunhal; b) real: compreendidas por meio de exames de pessoas ou coisas, pericias, bem como documental.

Assevera Humberto Theodoro Junior ${ }^{42}$ que para todo objeto existe uma forma de prová-la, e para tanto é permitido todos os meios em direito admitidas. Judicialmente a prova tem como objeto

\subsection{Meios de provas}

A Carta Magna, no artigo $5^{\circ}$, inciso LVI, assevera da vedação pela utilização de provas obtidas por meios ilícitos, e que sendo produzidas, são tidas como inexistente. Reza no inciso LVI, do artigo $5^{\circ}$, da Carta Magna que: "São inadmissíveis,

\footnotetext{
${ }^{40}$ Nesse sentido: COSTA, Marco Antônio Rebouças da. Considerações Sobre a Prova no Processo Civil. Acesso 11/07/2013. Disponível em: http://jus.com.br/revista/texto/11358/ consideracoes-sobre-a-prova-no-processo-civil. BERMUDES, Sergio. Direito Processual Civil. Estudos e pareceres. $2^{\text {a }}$ série. São Paulo: Saraiva. 1994. p. 50.

${ }^{41}$ MONTENEGRO FILHO, Misael. Curso de Direito Processual Civil. 9. ed. São Paulo: Atlas, 2004. p. 422.

42 THEODORO JÚNIOR, Humberto. Curso de Direito Processual Civil-Teoria geral do direito processual civil e processo de conhecimento. Vol. I. Rio de Janeiro: Forense, 2012.p.438.
} 
no processo, as provas obtidas por meios ilícitos".

É prova ilegal aquela que viola o ordenamento jurídico como um todo, compreende-se pela inobservância das leis e princípios gerais, quer sejam este de natureza material ou meramente processual ${ }^{43}$.

Entende-se por prova emprestada ${ }^{44}$ aquela entranhada em um processo diferente do qual se pretende utilizar. Esta é levada ao conhecimento do juiz e, para que nele gere os efeitos pretendidos pela parte, deve observar se no processo que a originou, serviu por exemplo como prova testemunhal, o processo que a teve de forma emprestada, diferentemente da sua valoração no processo que a emprestou, terá efeito meramente documental, ou seja, terá sua valoração apenas como documento, sendo questionável seu valor probante, principalmente se a prova emprestada não foi produzida no processo original entre as mesmas partes, ou se não foi submetida ao crivo do contraditório ${ }^{45}$.

Há diferentes fases de produzir uma prova, a fase da coleta de provas recebe o nome de procedimento probatório, que nada mais é que o andamento dos atos processuais referentes às provas a qual sempre deve respeitar o princípio constitucional do contraditório ${ }^{46}$.

A conviç̧ão do juiz deve ser estabelecida segundo meios ou instrumentos reconhecidos pelo direito como idôneo, neste sentido é o artigo 332, do Código de Processo civil: "Todos os meios legais, bem como os moralmente legítimos, ainda que não especificados neste Código, são hábeis para provar a verdade dos fatos, em que se funda a ação ou a defesa".

Outros meios de prova elencados no Código de Processo Civil tratam-se do depoimento pessoal, confissão, exibição de documento ou coisa, prova documental, prova testemunhal, prova pericial, inspeção judicial.

${ }^{43}$ MONTENEGRO FILHO, Misael. Curso de Direito Processual Civil. 9. ed. São Paulo: Atlas, 2004. p.436.

${ }^{44}$ Nesse sentido: SANTOS, Moacyr Amaral. Primeiras linhas de direito Processual Civil. $2^{\circ}$ vol. 22. ed. São Paulo: Saraiva. 2002. P.369. NERY JUNIOR, Nelson e ANDRADE NERY, Rosa Maria de. Código de Processo Civil Comentado e Legislação extravagante. $9^{\circ}$ Ed. São Paulo: Revista dos Tribunais, 2006. P. 528. MONTENEGRO FILHO, Misael. Curso de Direito Processual Civil. 9. ed. São Paulo: Atlas, 2004. p.456.

${ }^{45}$ NEVES, Daniel Amorim Assumpção. Manual de Direito Processual Civil. 3. ed. São Paulo: Método. 2011. p. 406.

${ }^{46}$ ALVIM, Arruda, ASSIS, Araken e ALVIM, Eduardo Arruda. Comentários ao Código de Processo Civil.Rio de Janeiro: G/Z Editora. 2012. p.515. 


\section{Poderes instrutórios do JUIZ}

\subsection{Atuação do Juiz dentro do Processo Civil}

O magistrado atua nos autos investido de jurisdição rumo à resolução de uma lide, e equilibrar os polos processuais.

Para Sérgio Alves Gomes apud Veruska Góis ${ }^{47}$ :

O caráter de relação pública ou o fenômeno da publicização do Processo Civil é o principal responsável pela concessão de maiores poderes ao juiz na direção do processo, incluindo nestes o de determinar a produção de provas, ainda que não requeridas pelas partes, quando necessário for para o conhecimento da verdade e a realização da justiça.

O Processo Civil ganhou importante vertente rumo autonomia científica, admitiu a sua abrangência enquanto elemento distinto da relação de direito material. No entanto, não perdeu de vista a instrumentalidade do processo que, manifesto enquanto relação de direito público tem como finalidade tutelar os bens de direito material ${ }^{48}$.

Prescreve o artigo 130 do Código de Processo Civil: "Caberá ao juiz, de ofício ou a requerimento da parte, determinar as provas necessárias à instrução do processo, indeferindo as diligências inúteis ou meramente protelatórias".

$\mathrm{O}$ artigo $5^{\circ}$ da Carta Magna assevera dentre outros direitos a garantia processual tanto na esfera cível, quanto administrativo e penal, o princípio do devido processo legal, inserto em várias das proposições constitucionais. Este é tido como um princípio basilar para os demais, quais sejam: direito ao contraditório e à ampla defesa, direito aos meios de prova em direito admitidos, direito à isonomia etc ${ }^{49}$.

É limitada à atuação do juiz, por exemplo, cita-se a vedação da produção de provas ilícitas, devendo o magistrado apreciar a casuística do que venha a ser meio ilícito ${ }^{50}$.

${ }^{47}$ GÓIS, Veruska Sayonara de. Os Limites do Poder Instrutório do Magistrado no Processo Civil. Disponível em: http://www.ajuris.org.br/index.php?option=com_content\&view=article\&id=147:os-limites-do-poder-instrutorio-do-magistrado-no-processo-civil\&catid=59:doutrina-nacional\&Itemid=20. Publicado em 06.05.2006. Acessado: 14.07.2013.

${ }^{48}$ GÓIS, Veruska Sayonara de. Os Limites do Poder Instrutório do Magistrado no Processo Civil. Disponível em: http://www.ajuris.org.br/index.php?option=com_content\&view=article\&id=147:os-limites-do-poder-instrutorio-do-magistrado-no-processo-civil\&catid=59:doutrina-nacional\&Itemid=20. Publicado em 06.05.2006. Acessado: 14.07.2013.

${ }^{49}$ NEVES, Daniel Amorim Assumpção. Manual de Direito Processual Civil. 3. ed. São Paulo: Método. 2011. p. 412.

${ }^{50}$ RENHART, Sérgio C., MARINONI, Luiz Guilherme. Comentários ao Código de Processo Civil. $5^{\circ}$ vol. Tomo I. Ed. São Paulo: Revista dos Tribunais, 2000. p.177. 
A ponderação é cabível ao juiz ao verificar a possibilidade em determiná -la - produção da prova. Caso opte pela pertinência, poderá determinar ex officio a chegada aos autos da prova obtida ilicitamente. Não pairam dúvidas no sentido de que esse ato seria uma exceção. O poder instrutório, não poderá ser afastado devido à ocorrência de eventual ilicitude ${ }^{51}$.

O princípio dispositivo em uma da ação é tido como um dos mais admiráveis limitadores da atividade probatória do magistrado. O princípio está inserto no artigo $2^{\circ}$ do Código de Processo Civil: "Nenhum juiz prestará a tutela jurisdicional senão quando a parte ou o interessado a requerer, nos casos e formais legais".

Inerte é a jurisdição devendo ser provocada pelos interessados. Assim, trata-se da disponibilidade das partes, quanto à iniciativa, na instauração do processo, e no incremento processual ${ }^{52}$.

Um contraponto ao princípio do dispositivo, está o inquisitivo, posto que este tende a uma liberalidade na formação da relação processual e no seu desenvolver pelo juiz. Na legislação pátria percebe-se que estes princípios são mesclados. Assevera o artigo 262, do CPC: "O processo civil começa por iniciativa da parte, mas se desenvolve por impulso oficial". Embutido neste contexto está o princípio dispositivo.

Disserta Vicente Greco Filho apud Veruska Góis ${ }^{53}$ que "o juiz tem poderes instrutórios, mas limitados em face do princípio dispositivo".

Nesse contexto o magistrado está engessado vez que o princípio dispositivo constitui uma hierarquia em termos de produção da prova, competindo inicialmente às partes, a responsabilidade quanto à instrução. Em caráter subsidiário, o juízo poderia determinar ex officio a produção probatória ${ }^{54}$.

Os autos são instrumentalizados a partir de suas narrações e pedidos pelas partes. O juiz, quando se vale do poder instrutório, baseia-se suas limitações impostas pela alegação das partes, valendo-se apenas dos fatos revelados no processo.

${ }^{51}$ GÓIS, Veruska Sayonara de. Os Limites do Poder Instrutório do Magistrado no Processo Civil. Disponível em: http://www.ajuris.org.br/index.php?option=com_content\&view=article\&id=147:os-limites-do-poder-instrutorio-do-magistrado-no-processo-civil\&catid=59:doutrina-nacional\&Itemid=20. Publicado em 06.05.2006. Acessado: 14.07.2013.

${ }^{52}$ Nesse sentido: MONTENEGRO FILHO, Misael. Código de processo civil comentado e interpretado. 3. ed. São Paulo: Atlas. 2013. p. 30. NERY JUNIOR, Nelson e ANDRADE NERY, Rosa Maria de. Código de Processo Civil Comentado e Legislação extravagante. 9. ed. São Paulo: Revista dos Tribunais, 2006. p. 141.

${ }^{53}$ GÓIS, Veruska Sayonara de. Os Limites do Poder Instrutório do Magistrado no Processo Civil. Disponível em: http://www.ajuris.org.br/index.php?option=com_content\&view=article\&id=147:os-limites-do-poder-instrutorio-do-magistrado-no-processo-civil\&catid=59:doutrina-nacional\&Itemid=20. Publicado em 06.05.2006. Acessado: 14.07.2013.

${ }^{54}$ MONTENEGRO FILHO, Misael. Curso de Direito Processual Civil. 9. ed. São Paulo: Atlas, 2004. p.424. 
Segundo leciona Nery Júnior apud Góis ${ }^{55}$.

Conforme mencionado anteriormente, segundo o artigo 130 do CPC, é incumbência do magistrado indeferir as diligências inúteis ou protelatórias, e assim, do que entender inútil ou protelatório, entra seu juízo de valor acerca do teor alegado, mostrado e necessário para a comprovação das versões apresentadas ${ }^{56}$.

Corrobora o sentido Solleon Menezes ${ }^{57}$ :

As partes podem requerer e o juiz pode determinar de ofício a produção de provas, sempre atendendo aos princípios da celeridade e economia processual, evitando diligências meramente protelatórias. Vale salientar que o juiz deve proceder com cautela quando agir ex officio na produção de provas, porque somente quando a questão versar sobre direitos indisponíveis ou quando as partes se desincumbirem de forma incompleta da produção probatória, pode o juiz, para formar seu convencimento, ordenar a seu critério e conveniência a produção de provas. Quando, ao contrário, a causa versar sobre direitos disponíveis e a parte não produziu prova, a lei presume que esta abriu mão de fazê-lo.

O fato que irá contribuir para se demonstrar o alegado pelas partes, entende-se por prova necessária.

Será necessária a prova quando sua presença ou ausência nos autos for capaz de influenciar na formação do convencimento do magistrado, ou seja, quando a prova for relevante ${ }^{58}$.

55 Nesse sentido: GÓIS, Veruska Sayonara de. Os Limites do Poder Instrutório do Magistrado no Processo Civil. Disponível em: http://www.ajuris.org.br/index.php?option=com_content $\&$ view $=$ article $\&$ id $=147$ :os-limites-do-poder-instrutorio-do-magistrado-no-processo-civil\&catid=59:doutrina-nacional\&Itemid $=20 . \quad$ Publicado em 06.05.2006. Acessado: 14.07.2013. MONTENEGRO FILHO, Misael. Código de processo civil comentado e interpretado.3. ed. São Paulo: Atlas. 2013. p. 304.

${ }^{56}$ NERY JUNIOR, Nelson e ANDRADE NERY, Rosa Maria de. Código de Processo Civil Comentado e Legislação extravagante. 9. ed. São Paulo: Revista dos Tribunais, 2006 .p. 339.

57 Nesse sentido: MENEZES, Solleon. Provas no Processo de Conhecimento do Processo Civil - Parte Geral. Disponível em: http://solleon.wordpress.com/2008/09/24/provasno-processo-de-conhecimento-do-processo-civil-parte-geral/. Acessado em: 14.07.2013. RENHART, Sérgio C., MARINONI, Luiz Guilherme. Comentários ao Código de Processo Civil. $5^{\circ}$ vol. Tomo I. Ed. São Paulo: Revista dos Tribunais, 2000. p. 202.

${ }^{58}$ NEVES, Daniel Amorim Assumpção. Manual de Direito Processual Civil. 3. ed. São Paulo: Método. 2011. p. 412. 


\subsection{Limites do Poder de Instrução}

Há no ordenamento duas presunções quanto ao poder de instrução, uma trata-se da presunção relativas, ou, iuris tantum e a outra, da presunção absoluta, ou, Iuri et de Iuri.

No caso de presunção absoluta há vedação para produção de provas ${ }^{59}$, devendo o juiz se limitar apenas ao in casu. Já na presunção relativa, caberá ao magistrado ponderar sobre o caso, a fim de averiguar as condições específicas e, os interesses envolvidos ${ }^{60}$. A revelia por exemplo, trata-se de um espécie de ficção processual, onde é admitido a verdade alegada nos autos e não contestadas pela parte contrária.

A fim de conferir segurança jurídica aos litigantes, pondera-se que nenhum poder instrutório conferido ao juiz será absoluto, preocupação está lançada pela doutrina a fim de não só guiar a iniciativa oficial, como também conferir segurança jurídica a quem litiga ${ }^{61}$.

É inerente ao magistrado o poder de instrução, visto que ele poderá determinar de ofício, ou a requerimento da parte a realização da prova dos fatos de real importância para a resolução da demanda, assim como muito bem relata Elpídio Donizetti ${ }^{62}$.

O dispositivo legal que trata dos poderes instrutórios do juiz é o artigo 130 do Código de Processo Civil, que prevê: "Caberá ao juiz, de ofício ou a requerimento da parte, determinar as provas necessárias à instrução do processo, indeferindo as diligências inúteis ou meramente protelatórias".

A priori nota-se que o princípio dispositivo tem em seu escopo uma limitação quanto aos poderes instrutórios do juiz, vez que, a função do juiz se tornaria incompatível com a disponibilidade das partes em relação ao objeto do litígio ${ }^{63}$.

Contudo, o magistrado ao verificar que certas situações não irão conflitar e nem mesmo excluir às pretensões das partes, poderá se valer do incremento dos

\footnotetext{
${ }^{59}$ RENHART, Sérgio C., MARINONI, Luiz Guilherme. Comentários ao Código de Processo Civil. $5^{\circ}$ vol. Tomo I. Ed. São Paulo: Revista dos Tribunais, 2000. p. 176.

${ }^{60}$ MONTENEGRO FILHO, Misael. Curso de Direito Processual Civil. 9. ed. São Paulo: Atlas, 2004. p. 446.

${ }^{61}$ Nesse sentido: XAVIER, Trícia Navarro. Poderes Instrutórios do Juiz no Processo de Conhecimento. Disponível em: http://www.ccje.ufes.br/direito/posstrictosensumestrado/Links/ dissertacaotriciaxavier.pdf Acessado aos: 14.07.2013. MONTENEGRO FILHO, Misael. Código de processo civil comentado e interpretado.3. ed. São Paulo: Atlas. 2013. p. 305.

${ }^{62}$ DONIZETTI, Elpídio. Curso didático de direito Processual Civil. 15. ed. São Paulo: Atlas. 2011. p. 551.

${ }^{63}$ Nesse sentido: MONTENEGRO FILHO, Misael. Código de processo civil comentado e interpretado.3. ed. São Paulo: Atlas. 2013. p. 183. NERY JUNIOR, Nelson e ANDRADE NERY, Rosa Maria de. Código de Processo Civil Comentado e Legislação extravagante. 9. ed. São Paulo: Revista dos Tribunais, 2006 . p. 339. MONTENEGRO FILHO, Misael. Curso de Direito Processual Civil. 9. ed. São Paulo: Atlas, 2004. p. 441.
} 
poderes instrutórios, haja vista não encontrar impedimentos no princípio dispositivo. Tal quanto assevera Trícia Navarro ${ }^{64}$ :

Os atos de disposição das partes dentro do processo conservam-se intactos, ao passo que ao magistrado cabe a direção e o controle do ritmo do feito. Assim, a marcha processual não fica vulnerável aos desígnios das partes ${ }^{65}$.

É um obstáculo ao princípio da isonomia à ampla aplicação do artigo 130 do Código de Processo Civil, portanto esta afirmação não deverá prosperar, pois uma conduta assertiva para estabelecer às partes uma igualdade substancial nos autos, condiz justamente em praticar o magistrado o não favorecimento a qualquer dos litigantes. "As apontadas ofensas a este princípio fundam-se na ultrapassada concepção de disponibilidade das provas pelas partes"

Já em relação ao princípio da imparcialidade do juiz, é um atributo em que as partes não participam, pois as mesmas têm interesse no desenrolar do processo, devendo então a contratio sensu a mitigação da conduta parcial das mesmas ${ }^{67}$.

Há uma parte da doutrina que atribuem limitação ao artigo 131 do Código de Processo Civil, que assevera: "O juiz apreciará livremente a prova, atendendo aos fatos e circunstâncias constantes dos autos, ainda que não alegados pelas partes; mas deverá indicar, na sentença, os motivos que lhe formaram o convencimento".

Sérgio Mattos corrobora ${ }^{68}$ : "[...] o ativismo do juiz em tema de prova esbarraria nos limites do material fático aportado à causa”.

No entanto Leonardo Greco ${ }^{69}$ :

\footnotetext{
${ }^{64}$ XAVIER, Trícia Navarro. Poderes Instrutórios do Juiz no Processo de Conhecimento. Disponível em: http:/www.ccje.ufes.br/direito/posstrictosensumestrado/Links/dissertacaotriciaxavier.pdf Acessado aos: 14.07.2013.

65 XAVIER, Trícia Navarro. Poderes Instrutórios do Juiz no Processo de Conhecimento. Disponível em: http:/www.ccje.ufes.br/direito/posstrictosensumestrado/Links/dissertacaotriciaxavier.pdf Acessado aos: 14.07.2013.

66 XAVIER, Trícia Navarro. Poderes Instrutórios do Juiz no Processo de Conhecimento. Disponível em: http://www.ccje.ufes.br/direito/posstrictosensumestrado/Links/dissertacaotriciaxavier.pdf Acessado aos: 14.07.2013.

${ }^{67}$ NERY JUNIOR, Nelson e ANDRADE NERY, Rosa Maria de. Código de Processo Civil Comentado e Legislação extravagante. 9. ed. São Paulo: Revista dos Tribunais, 2006 .p. 341.

68 XAVIER, Trícia Navarro. Poderes Instrutórios do Juiz no Processo de Conhecimento. Disponível em: http:/www.ccje.ufes.br/direito/posstrictosensumestrado/Links/dissertacaotriciaxavier.pdf Acessado aos: 14/7/2013.

${ }^{69}$ Nesse sentido: XAVIER, Trícia Navarro. Poderes Instrutórios do Juiz no Processo de Conhecimento. Disponível em: http:/www.ccje.ufes.br/direito/posstrictosensumestrado/Links/ dissertacaotriciaxavier.pdf Acessado aos: 14.07.2013. MONTENEGRO FILHO, Misael. Código de processo civil comentado e interpretado.3. ed. São Paulo: Atlas. 2013. p. 185.
} 
Para evitar o juiz investigador, o que comprometeria a sua imparcialidade, a sua iniciativa probatória deve limitar-se aos elementos probatória deve limitar-se aos elementos probatórios cuja existência resulte dos autos.

No que tange à doutrina, esta dá a lide ou ao seu objeto controvertido uma limitação quanto à iniciativa probatória. Neste tema trata João Batista Lopes ${ }^{70}$ :

Cabe advertir, por último, que as iniciativas probatórias do juiz devem limitar-se aos fatos controvertidos do processo, não lhe sendo lícito alterar a causa petendi, introduzindo fatos ou fundamentos novos.

Discorre Arruda Alvim ${ }^{71}$ o quanto segue:

Em face do que dispõe o art. 130 do CPC, a única limitação à atividade do juiz com relação à atividade instrutória é a de que a ele não é dado ir além do tema probatório, ou seja, da lide ou do objeto litigioso, nem infringir o princípio do ônus (subjetivo) da prova.

Corrobora ao entendimento de Arruda Alvim, o José Roberto Bedaque ${ }^{72}$ :

Em princípio, pode-se dizer que os elementos objetivos da demanda constituem a primeira limitação. À luz do princípio da correlação ou adstrição, a sentença deve ater-se ao pedido e à causa de pedir (CPC, arts. 128 e 460). Se assim é, não pode o juiz buscar provas relativas a fatos não submetidos ao contraditório.

Ressalta-se a definição atribuída ao magistrado por Leonardo Greco ${ }^{73}$ :

A definição de limites entre os poderes do juiz e a autonomia das partes está diretamente vinculada a três fatores: a) à disponibilidade do próprio direito material posto em juízo; b) ao respeito ao equilíbrio entre as partes

70 XAVIER, Trícia Navarro. Poderes Instrutórios do Juiz no Processo de Conhecimento. Disponível em: http:/www.ccje.ufes.br/direito/posstrictosensumestrado/Links/dissertacaotriciaxavier.pdf Acessado aos: 14.07.2013.

${ }^{71}$ ARRUDA ALVIM NETTO, José Manoel de. Manual de direito processual civil: parte geral. 9. ed. rev., atual. e ampl. São Paulo: Revista dos Tribunais, 2005. v. 1. p. 392.

72 BEDAQUE, José Roberto dos Santos. Direito e processo: influência do direito material sobre o processo. São Paulo: Malheiros, 1995. p. 154.

${ }^{73}$ GRECO, Leonardo. Os atos de disposição processual: primeiras reflexões. Revista Eletrônica de Direito Processual, out./dez. 2007. Disponível em: http://www.e-publicacoes.uerj. br/index.php/quaestioiuris/article/download/3691/2561. Acessado em: 14.07.2013. 
e a paridade de armas, para que uma delas, em razão dos atos de disposição seus ou de seu adversário, não se beneficie de sua particular posição de vantagem em relação à outra quanto ao direito de acesso aos meios de ação e de defesa; e c) à preservação da observância dos princípios e garantias fundamentais do processo no Estado Democrático de Direito.

Portanto, entende que o poder instrutório do juiz pode ser visto por diversos ângulos, e assim, cada ponto de vista relaciona a uma restrição pontual. Desta senda, verifica-se necessário identificar a finco qual é o melhor sentido a ser aplicado nas provas $^{74}$.

Para impugnar os limites formados pela doutrina, existe uma árdua tarefa, ainda que o objetivo seja somente atear o disputa acerca do tema no mundo jurídico.

Os basilares limites fundados pela doutrina tratam-se: imparcialidade; fatos e circunstâncias constantes dos autos; lide ou objeto litigioso; princípio do ônus subjetivo da prova; contraditório e ampla defesa e princípios da demanda, legalidade e motivação.

Com a análise do artigo 130 do CPC, assiste-se que o código não aplica o princípio dispositivo em sua plenitude. Se a parte tem a seu favor a ação, que só pode ser ajuizado por ela, interessada, após o ajuizamento dos autos, o impulso do processo é oficial.

Há que se ter a reflexão, além do interesse da parte, a verificação quanto à lide em si e, o interesse estatal, em ver o litígio resolvido de forma justa e seguindo as regras do Direito ${ }^{75}$. Júnior $^{76}$ :

Em outros tempos não se via por este prisma, discorre Humberto Theodoro

Em Roma, por exemplo, não se atribuía ao juiz a atividade investigatória, que ficava a cargo apenas das partes, princípio que perdurou na Idade Média entre os povos que se orientavam pelas tradições romano-germânicas. Foi somente a partir do Código Prussiano (1793-1795) que se ensaiou, durante algum tempo, o regime de investigação probatória a cargo do juiz. No século XIX, enfim, graças à influência dos Códigos de Processo Civil do Cantão de Genebra (1819) e da Áustria (1895) e, sobretudo, sob a influência de Franz Klein, os poderes do juiz em tema de apuração da verdade foram acentuados. Daí em diante o processo civil europeu continental, assim como os dos países ocidentais dele derivados, generalizou a iniciativa probatória do juiz como uma das mais importantes características do processo justo, cuja finalidade tutelar não pode se afastar da busca da verdade real,

${ }_{74}$ MONTENEGRO FILHO, Misael. Curso de Direito Processual Civil. 9. ed. São Paulo: Atlas, 2004. p. 436.

${ }^{75}$ MONTENEGRO FILHO, Misael. Código de processo civil comentado e interpretado.3. ed. São Paulo: Atlas. 2013. p. 184.

${ }^{76}$ THEODORO JÚNIOR, Humberto. Curso de Direito Processual Civil-Teoria geral do direito processual civil e processo de conhecimento. Vol. I. Rio de Janeiro: Forense, 2012.p.444. 
na medida do possível.

Isso posto, hodiernamente o magistrado deixou de ser simples árbitro, e investiu de poderes inerentes a sua jurisdição em busca verdade real para resolução da lide.

Evidente que este poder é ponderado dentro de limites principiológico quanto aos ônus processuais e presunções legais, na maioria das vezes a vontade ou a conduta da parte influi decisivamente sobre a prova e afasta a iniciativa do juiz nessa matéria ${ }^{77}$.

Assim, ocorre quando o réu não se defende a ação, e esta não versa sobre direitos indisponíveis, ou ainda, na defesa, deixar de opor exatamente os fatos ou, algum fato exposto na inicial.

Sobrevém então à presunção legal da veridicidade dos fatos expostos que se volveram incontroversas nos termos dos arts. 319 e 302 do Código de Processo Civil $^{78}$.

Discorre de Humberto Theodoro Junior ${ }^{79}$ :

Também a confissão, de forma expressa ou como consequência de recusa a depoimento pessoal, tem grande efeito sobre a prova. Uma vez estabelecida a verdade plena acerca do fato constitutivo do direito disputado no processo, por força da confissão, não cabe iniciativa alguma do juiz para buscar outras provas contra a versão do confitente, máxime quando se tratar de litígio acerca de direitos disponíveis.

Dantes a doutrina encontrava no ônus da prova, uma barreira se o juiz tomasse ação de gerar uma prova não diligenciada oportunamente pela parte interessada. Tão somente nos estados de embaraço entre elementos de convicção colidentes, já existentes nos autos, é que se aceitava o juiz, de ofício, produzir outras provas ${ }^{80}$.

Posto que acima do ônus da prova - cujas regras atuam na fase derradeira de julgamento da lide e não durante a colheita dos elementos de instrução da causa - utilizar-se o ajuste com a verdade real.

\footnotetext{
77 VÍDERO, Samantha. Teoria Geral da Prova no Direito Processual Civil. Disponível em: http://www.viajus.com.br/viajus.php?pagina=artigos\&id=1507\&idAreaSel=15\&seeArt=yes . Acessado em: 14.07.2013.

${ }^{78}$ NERY JUNIOR, Nelson e ANDRADE NERY, Rosa Maria de. Código de Processo Civil Comentado e Legislação extravagante. 9. ed. São Paulo: Revista dos Tribunais, 2006 .p. 517. 79 THEODORO JÚNIOR, Humberto. Curso de Direito Processual Civil - Teoria geral do direito processual civil e processo de conhecimento. Vol. I. Rio de Janeiro: Forense, 2012.p. 444.

80 Nesse sentido: FRANCO, Sandra Rose de Mendes Freire e. Os limites do poder instrutório do juiz. Disponível em: http://www.ambitojuridico.com.br/site/index.php?n_link=revista_artigos_leitura\&artigo_id=10885. Acessado em: 14.07.2013. NERY JUNIOR, Nelson e ANDRADE NERY, Rosa Maria de. Código de Processo Civil Comentado e Legislação extravagante. $9^{\circ}$ Ed. São Paulo: Revista dos Tribunais, 2006 .p. 5.
} 
Sem interdição de a iniciativa probatória do julgador deparam-se cultivada na maioria dos Códigos modernos, poucas vozes hostis à liberdade judicial de encalço da verdade real, sob o ensejo de que a elevação de tal poder, fragilizaria a imparcialidade do julgador, que é elemento indispensável a feitio do devido processo legal, jamais podendo ser ele parcial.

Existem meios de limitação para conservar imparcialidade do juiz, eles não causam sua inércia diante da iniciativa da busca da verdade real. Os remédios contra os danos que a parcialidade pode transmitir a presteza do juiz são outros, e segundo Taruffo apud Theodoro $\mathrm{Jr}^{81}$ :

Consistem na plena atuação do contraditório das partes, também por obra do próprio juiz, e na necessidade de que ele redija uma motivação analítica e completa, racionalmente estruturada, sobre a base de justificações controláveis, para a decisão sobre os fatos.

Dessa forma, no processo atual, o juiz jamais pode ficar alheio da observação da verdade material. Essa atuação do magistrado objetiva não apenas a propiciar a ligeira solução do litígio e o encontro da verdade real, mas também a apresentar às partes uma assistência judicial. No entender de Fritz Bauer apud Humberto Theodoro Junior ${ }^{82}$ :

Não devem reverter em prejuízo destas o desconhecimento do direito, a incorreta avaliação da situação de fato, a carência em matéria probatória; cabe ao juiz sugerir-lhes que requeiram as providências necessárias e ministrem material de fato suplementar, bem como introduzir no processo as provas que as partes desconhecem ou lhes sejam inacessíveis.

Porém, cabe ao juiz o cuidado para não comprometer a sua imparcialidade na condução do processo. A necessidade da prova, ordenada de ofício, deve surgir do contexto do processo e não de atividade fora dos autos, sugerida por diligências e conhecimentos pessoais ou particulares auferidos pelo magistrado fora do controle do contraditório.

Conforme adverte Humberto Theodoro Júnior ${ }^{83}$, "os poderes conferidos

${ }^{81}$ THEODORO JÚNIOR, Humberto. Curso de Direito Processual Civil - Teoria geral do direito processual civil e processo de conhecimento. Vol. I. Rio de Janeiro: Forense, 2012. p. 45.

82 THEODORO JÚNIOR, Humberto. Curso de Direito Processual Civil - Teoria geral do direito processual civil e processo de conhecimento. Vol. I. Rio de Janeiro: Forense, 2012. p. 446.

83 THEODORO JÚNIOR, Humberto. Curso de Direito Processual Civil - Teoria geral do direito processual civil e processo de conhecimento. Vol. I. Rio de Janeiro: Forense, 2012. p. 446. 
ao juiz, em matéria de investigação probatória, engendram a figura do juiz ativo, mas não do juiz autoritário".

Sua cooperação na busca da verdade real não tem o bojo de anular ou impedir a iniciativa competente das partes. Trata-se de atividade integrativa e supletória $^{84}$, de modo que, quando estas praticam seus poderes para produzir todas as provas disponíveis e o abastecem dos elementos satisfatórios para a verificação dos fatos proeminentes da causa, não há nenhuma indigência de que o juiz use seus poderes instrutórios.

Nesse estreito endividamento não é com a posição de qualquer das partes, mas com a veracidade, sem a qual não se alcança a justiça, para efetivação da tutela jurisdicional no Estado Democrático de Direito.

O magistrado que faz concordar seu poder, para empenhar a prova apenas dos fatos que velam e patrocinam uma das partes, equivoca-se gravemente, pois nessa conjunção em ser neutro, embaraça o quadro fático do litígio.

Tão ou mais grave é a atitude de insensibilidade à verdade, quando cabe à abrangência do juiz o meio de desvendá-lo. Ao eleger julgar o litígio, na sombra da imprecisão e fria técnica, decisivamente, pode-se subentender que esse não é um julgador empenhado com os nortes constitucionais do equitativo processo ansiado pelo contemporâneo Estado de Direito.

\section{TEORIA DINÂMICA DA DIVISÃo DINÂMICA do ÔNUS DA PROVA}

\subsection{Fontes de Provas}

São fontes de prova às pessoas e as coisas e são meio de provas os instrumentos utilizados para obtê-las - as fontes. Estes são os elementos que ajudarão o magistrado a formar sua convicção ${ }^{85}$.

Há fontes reais e pessoais. Sendo que as fontes pessoais são adquiridas diretamente por pessoas, sejam testemunhas por exemplo. Já, são fontes reais aquelas que dependem de interpretação, a exemplo a prova pericial, a prova documental.

Neste sentido, corrobora Humberto Theodoro Junior ${ }^{86}$ :

Fonte é aquilo que se utiliza para comprovar o fato inspecionado (como o

\footnotetext{
$\overline{84}$ THEODORO JÚNIOR, Humberto. Curso de Direito Processual Civil - Teoria geral do direito processual civil e processo de conhecimento. Vol. I. Rio de Janeiro: Forense, 2012. p. 446.

${ }^{85}$ KNIJNIK, Danilo. A prova nos juízos Cível, Penal e Tributário. Rio de Janeiro: Forense. 2007. p. 32.

${ }^{86}$ THEODORO JÚNIOR, Humberto. Curso de Direito Processual Civil - Teoria geral do direito processual civil e processo de conhecimento. Vol. I. Rio de Janeiro: Forense, 2012. p. 438.
} 
relato in concreto de uma testemunha, o efetivo conteúdo de um documento, o teor de uma confissão, ou a informação técnica prestada pelo perito).

\section{2. Ônus da Prova aCepÇão geral}

Tal como já depreendido neste estudo, o princípio do dispositivo é de suma importância para o Processo Civil, este, por sua vez recebe relevância quanto ao ônus da prova ${ }^{87}$.

Trata o princípio do dispositivo que devido o autor indicar na exordial os fundamentos de fato que baseiam o pedido, recai ao magistrado a observância em sentenciar no mesmo sentido, para não recair em decisão extra, ultra ou cintra peti$t a$, e assim, decidir de forma nula ${ }^{88}$.

Ressalta-se que a prova é um ônus, e não um dever, portanto, em caso da sua não apresentação/colhida, implicará em prejudicar uma das partes, no sentido de os litigantes assumem o risco em não obter êxito na demanda e assim, deixar de provar os fatos alegados estes, que por sorte dependiam da existência do direito subjetivo, o qual se pretendia proteger por meio da tutela jurisdicional ${ }^{89}$.

Assim, entende-se por verídica a atribuição do fato alegado e não provado, o mesmo que dizer: "ser inexistente" 90 .

Quem aduz um direito, pretende prová-lo e para tanto, o ônus da prova é a necessidade em provar para lograr êxito na demanda.

$\mathrm{O}$ réu no momento em que contesta se defende do litígio, e nega o fato o qual é baseado a pretensão do Autor da demanda, terá à sua incumbência provar o fato impeditivo, modificativo, ou extintivo.

Assim, ao se defender de forma indireta, o Réu invoca fato capaz de alterar ou eliminar (fato modificativo ou extintivo) as consequências jurídicas daquele outro fato invocado pelo autor, a regra inverte-se e passa ao autor o ônus em provar $^{91}$.

Neste sentido trata o artigo 333, do Código de Processo Civil:

Art. 333. O ônus da prova incumbe: I - ao autor, quanto ao fato consti-

\footnotetext{
${ }^{87}$ Nesse sentido: KNIJNIK, Danilo. A prova nos juízos Cível, Penal e Tributário. Rio de Janeiro: Forense. 2007. P. 20. ALVIM, Arruda, ASSIS, Araken e ALVIM, Eduardo Arruda. Comentários ao Código de Processo Civil.Rio de Janeiro: G/Z Editora. 2012. p. 518.

${ }^{88}$ LENZA, Pedro e GONÇALVES, Marcus Vinicius Rios. Direito Processual Civil esquematizado. $3^{\text {a }}$ Ed. São Paulo: Saraiva, 2012. p. 75.

89 KNIJNIK, Danilo. A prova nos juízos Cível, Penal e Tributário. Rio de Janeiro: Forense. 2007. p. 19.

${ }^{90}$ ALVIM, Arruda, ASSIS, Araken e ALVIM, Eduardo Arruda. Comentários ao Código de Processo Civil.Rio de Janeiro: G/Z Editora. 2012. p. 517

${ }^{91}$ ALVIM, Arruda, ASSIS, Araken e ALVIM, Eduardo Arruda. Comentários ao Código de Processo Civil.Rio de Janeiro: G/Z Editora. 2012. p. 518.
} 
tutivo do seu direito; II - ao réu, quanto à existência de fato impeditivo, modificativo ou extintivo do direito do autor. Parágrafo único. É nula a convenção que distribui de maneira diversa o ônus da prova quando: I recair sobre direito indisponível da parte; II - tornar excessivamente difícil a uma parte o exercício do direito.

\section{Como muito bem aponta Elpídio Donizetti ${ }^{92}$ :}

É inerente as partes a indicação na peça inaugural e na defesa, demonstrar os meios de provas que se pretende se valer a fim de demonstrarem suas alegações (art. 282, $\mathrm{VI}^{93}$ e $300^{94}$, in fine do CPC). Serão na fase de encerramento postulatório que se fixará os pontos controvertidos e, individualizado as providências preliminares (artigo $324^{95}$, in fine, do CPC). E ainda sim, apesar de o artigo 324, in fine, facultar apenas ao autor a oportunidade de individualização dos meios probatórios, em face do réu, ao juiz é assegurado conceder tratamento igualitário às partes, nos termos do quanto assevera o artigo 125 , I do $\mathrm{CPC}^{96}$.

A título de exemplo cita uma lide com base em Ação de despejo por falta de pagamento, caso o Réu venha alegar a inexistência da relação contratual, o ônus da prova, será do autor. Contudo, se alegar pagamento prévio dos aluguéis reclamados (fato modificativo ou extintivo), o onus probandi será seu ${ }^{97}$.

Quanto da distinção entre negação do fato e fato negativo aponta a Humberto Theodoro Júnior ${ }^{98}$ :

92 DONIZETTI, Elpídio. Curso didático de direito Processual Civil. 15 ${ }^{\mathrm{a}}$ Ed. São Paulo: Atlas. 2011. p. 551.

${ }^{93}$ Art. 282.a petição inicial indicará: (...)VI - as provas com que o autor pretende demonstrar a verdade dos fatos alegados(...)

${ }^{94}$ Art. 300. Compete ao réu alegar, na contestação, toda a matéria de defesa, expondo as razões de fato e de direito, com que impugna o pedido do autor e especificando as provas que pretende produzir.

${ }^{95}$ Art. 324. Se o réu não contestar a ação, o juiz, verificando que não ocorreu o efeito da revelia, mandará que o autor especifique as provas que pretenda produzir na audiência.

${ }^{96}$ Art. 125. O juiz dirigirá o processo conforme as disposições deste Código, competindo-lhe: $\mathrm{I}$ - assegurar às partes igualdade de tratamento (...).

${ }^{97}$ KNIJNIK, Danilo. A prova nos juizos Cível, Penal e Tributário. Rio de Janeiro: Forense. 2007. P. 165. ALVIM, Arruda, ASSIS, Araken e ALVIM, Eduardo Arruda. Comentários ao Código de Processo Civil.Rio de Janeiro: G/Z Editora. 2012. p. 519.

98 Nesse sentido: THEODORO JÚNIOR, Humberto. Curso de Direito Processual Civil Teoria geral do direito processual civil e processo de conhecimento. Vol. I. Rio de Janeiro: Forense, 2012.P.447. RENHART, Sérgio C., MARINONI, Luiz Guilherme. Comentários ao Código de Processo Civil. $5^{\circ}$ vol. Tomo I. Ed. São Paulo: Revista dos Tribunais, 2000. p. 200. 
A simples negação do fato constitutivo, naturalmente, não reclama prova de quem a faz. O fato negativo, porém, aquele que funciona como fato constitutivo de um direito, tem sua prova muitas vezes exigida pela própria lei. É o que ocorre, por exemplo, com a prova do não uso, por 10 anos, para extinguir-se a servidão (Código Civil de 1916, art. 710, III; CC de 2002; art. 1.389, III), ou da omissão culposa, em matéria de responsabilidade civil (CC de 1916, art. 159; CC de 2002, arts. 186 e 927). Em casos como esses, a parte que alega o fato negativo terá o ônus de prová-lo.

Aponta Marcus Vinicius Rios Gonçalves ${ }^{99}$ finalmente que em relação às regras do ônus da prova caso esgote todos os meios de possibilidade para provar um fato, e este não tiver sido aclarado, havendo qualquer outro meio e a outra parte da demanda puder contribuir para a formação do convencimento do juiz, ele deverá determiná-la de ofício, assim é este o sentido que trataremos no item abaixo.

\subsection{TeORIA dA DIVISÃo dinÂMICA do ÔNUS DA PROVA COMO FORMA DE ATENDI- MENTO DO ACESSO À JUSTIÇA}

Hodiernamente discute-se entre os doutrinadores se ainda prevalece o entendimento de que o ônus da prova seja rígido e estático, isto porque se distribui prévia e abstratamente o encargo probatório ${ }^{100}$.

Vez que o magistrado sente-se engessado por vezes, ao pretender acessar a verdade real, isto se prevalecer o entendimento de que a apreciação do litígio deve ser rigorosamente imposta da literalidade do artigo 333, do CPC. E ainda, como muito bem assevera Eupídio Donizetti:

Por desconsiderar as especificidades e particularidades do caso concreto, a distribuição previa do ônus de prova pode, em determinadas circunstâncias, tornar a tarefa de produzir a prova demasiado árdua para uma das partes, afastando-se, pois, da ideia comum de justiça.

Neste sentido há vasto entendimento jurisprudencial e doutrinário a fim de admitir o amortecimento no rigor da distribuição do ônus da prova traçado pelo artigo 333, do $\mathrm{CPC}^{101}$.

99 LENZA, Pedro e GONÇALVES, Marcus Vinicius Rios. Direito Processual Civil esquematizado. 3. ed. São Paulo: Saraiva, 2012. p. 76.

${ }^{100}$ DONIZETTI, Elpídio. Curso didático de direito Processual Civil. 15. ed. São Paulo: Atlas. 2011. p. 553.

${ }^{101}$ Nesse sentido: ALVIM, Arruda, ASSIS, Araken e ALVIM, Eduardo Arruda. Comentários ao Código de Processo Civil.Rio de Janeiro: G/Z Editora. 2012. pp. 515-19. NEGRÃO, Theotonio e GOUVÊA, José Roberto F. Código de Processo civil e legislação processual em 
Aduz Humberto Theodoro Júnior ${ }^{102}$ :

Fala-se em distribuição dinâmica do ônus probatório, por meio do qual seria, no caso concreto, conforme a evolução do processo, atribuído pelo juiz o encargo da prova à parte que detivesse conhecimentos técnicos ou informações específicas sobre os fatos discutidos na causa, ou, simplesmente, tivesse maior facilidade na sua demonstração. Com isso, a parte encarregada de esclarecer os fatos controvertidos poderia não ser aquela que, de regra, teria que fazê-lo.

Portanto, menciona-se que os elementos já apontados nos autos tornem verossímil a versão afirmada por uma das partes e, que para tanto o magistrado, na fase de saneamento, determine a produção das provas que entender necessárias, e ainda, defina a nova responsabilidade pela respectiva produção ${ }^{103}$.

Essa possibilidade não se trata de revogação do sistema do direito positivo, mas sim, de complementá-lo à luz de princípios inspirados no ideal de um processo justo, comprometido, sobretudo com a verdade real e com os deveres de boa-fé e lealdade que transformam os litigantes em cooperadores do juiz no aprimoramento da boa prestação jurisdicional ${ }^{104}$.

De qualquer sorte, esse abrandamento do rigor da literalidade do artigo 333, do Código de Processo Civil dependerá das condições particulares do caso em concreto, vez que o desenvolvimento do processo seja capaz de admitir um juízo de verossimilhança em torno da versão de uma das partes, capaz de sugerir, primordialmente, a possibilidade de o fato ter ocorrido, tal como afirma o litigante, a que compete o ônus de prova, mas que, nas circunstâncias, evidencie menos capacidade a esclarecê-lo por completo ${ }^{105}$.

Deste modo, havendo prova inacabada, mas configurada a verossimilhança o juiz estará autorizado em estabelecer o aclaramento completo do que ocorreu ao outro litigante, ou seja, àquele que detenha, de fato, e condições de evidenciar que o evento não teria se passado de acordo com o afirmado pela parte considerada hipos-

vigor. 39. ed. São Paulo: Saraiva. 2007. p. 475.

102 THEODORO JÚNIOR, Humberto. Curso de Direito Processual Civil - Teoria geral do direito processual civil e processo de conhecimento. Vol. I. Rio de Janeiro: Forense, 2012.p. 448.

${ }^{103}$ RENHART, Sérgio C., MARINONI, Luiz Guilherme. Comentários ao Código de Processo Civil. $5^{\circ}$ vol. Tomo I. Ed. São Paulo: Revista dos Tribunais, 2000. p. 39.

${ }^{104}$ Machado \& Mallmann. Disponível em: http://machadoemallmann.com.br/publicacoes?$\mathrm{cd}=3$. Acessado em: 14.07.2013

${ }^{105}$ Castro, Ana Paula de. Disponível em: http://www.ambitojuridico.com.br/site/?n_link=revista_artigos_leitura\&artigo_id=90\%2096. Acessado em: 14.07.2013. 
suficiente, em termos probatórios ${ }^{106}$.

A não deleção dos fatos constitutivos do direito praticados em juízo, por aquele contra quem o ônus fora invertido, ocasionará o êxito daquele que do mesmo ônus fora liberado. O juízo, antes de verossimilhança, se consolidará graças ao novo rumo emprestado à distribuição dinâmica do ônus da prova ${ }^{107}$.

Deve haver devido respeito acerca dessa excepcional posição do juiz, para não se tornar arbitrária, e para tanto, necessário que a decisão alteradora dos quesitos tratados no artigo 333, do CPC seja feita racionalmente ${ }^{108}$. De acordo com o entendimento de Luiz Guilherme Marononi apud Humberto Theodoro Júnior ${ }^{109}$ :

O juiz deverá, ao ordenar a inversão, proferir um julgamento lógico, capaz de revelar e fazer compreender, através de adequada fundamentação, como formou de maneira racional sua convicção, e quais os elementos que a determinaram.

Esta teoria merece total atenção, posto que a mesma não se presta a dispensar totalmente do ônus da prova por aquela parte que, segundo o artigo supra mencionado, tem o dever legal de provar a base fática de sua pretensão, mas somente de aliviá-la de algum aspecto do evento probatório, para o qual não tem acesso ou condições de investigação suficiente, ao passo que o adversário se acha em situação de fazê-lo ${ }^{110}$.

Para assegurar a correta aplicação dessa teria, é necessário verificar o quanto aponta Humberto Theodoro Júnior ${ }^{111}$ :

A) a parte que suporta o redirecionamento não fica encarregada de provar o fato constitutivo do direito do adversário; sua missão é a de esclarecer o fato controvertido apontado pelo juiz, o qual já deve achar-se parcial ou

106 NEVES, Daniel Amorim Assumpção. Manual de Direito Processual Civil. 3. ed. São Paulo: Método. 2011. p. 421.

${ }^{107}$ RENHART, Sérgio C., MARINONI, Luiz Guilherme. Comentários ao Código de Processo Civil. $5^{\circ}$ vol. Tomo I. Ed. São Paulo: Revista dos Tribunais, 2000. p.39.

${ }^{108}$ ALVIM, Arruda, ASSIS, Araken e ALVIM, Eduardo Arruda. Comentários ao Código de Processo Civil. Rio de Janeiro: G/Z Editora. 2012. p. 517.

109 THEODORO JÚNIOR, Humberto. Curso de Direito Processual Civil - Teoria geral do direito processual civil e processo de conhecimento. Vol. I. Rio de Janeiro: Forense, 2012. p. 449.

110 KOMMERS, Ezequiel Rodrigo. O Ônus Dinâmico da Prova no Processo Civil Brasileiro. Disponível em:http://bibliodigital.unijui.edu.br:8080/xmlui/bitstream/handle/123456789/1326/TC\%20para\%20entrega.pdf?sequence=1 Acessado: 14.07.2013.

111 THEODORO JÚNIOR, Humberto. Curso de Direito Processual Civil - Teoria geral do direito processual civil e processo de conhecimento. Vol. I. Rio de Janeiro: Forense, 2012. p. 449. 
indiciariamente demonstrado nos autos, de modo que a diligência ordenada tanto pode confirmar a tese de um como de outro dos litigantes; mas, se o novo encarregado do ônus da prova não se desempenhar a contento da tarefa esclarecedora, sairá vitorioso aquele que foi aliviado, pelo juiz, da prova completa do fato controvertido; B) a prova redirecionada deve ser possível; se nenhum dos contendores tem condição de provar o fato, não se admite que o juiz possa aplicar a teoria da dinamização do ônus probandi; para aplica-la de forma justa e adequada, o novo encarregado terá de ter condições efetivas de esclarecer o ponto controvertido da apuração da verdade real; se tal não ocorrer, o ônus da prova continuará regido pela regra legal estática, isto é, pelo artigo 333; C) a redistribuição não pode representar surpresa para a parte, de modo que a deliberação deverá ser tomada pelo juiz, com intimação do novo encarregado do ônus da prova esclarecedora, a tempo de proporcionar-lhe oportunidade de se desincumbir a contento do encargo; não se tolera que o juiz, de surpresa, decida aplicar a dinamização no momento de sentenciar; o processo justo é aquele que se desenvolve às claras, segundo os ditames do contraditório e ampla defesa, em constante cooperação entre as partes e o juiz, e, também, entre o juiz e as partes, numa completa reciprocidade entre todos os sujeitos do processo.

O Superior Tribunal de Justiça, em seu Recurso Especial no 316.316/PR, citado por Humberto Theodoro Júnior ${ }^{12}$, menciona que poderá ser exemplarmente utilizado o sentido qual demonstra a aplicação de maneira justa, a dinamização da prova: ao apreciar uma causa entre o adquirente de cartela de "telebingo" e, a empresa promotora do sorteio pela televisão, referido Acórdão aduziu que ao consumidor bastaria comprovar que se achava habilitado ao concurso, mediante exibição da cartela e do registro dos números sorteados.

O sistema da distribuição dinâmica do ônus da prova pode ser compatibilizado com o direito positivo brasileiro, posto reconhecer a princípio, todos os meios legais, bem como os moralmente legítimos, ainda que não elencados no Código de Processo Civil.

Este meio é tido como hábil para o fim de se provar a verdade dos fatos, ao qual foi fundada a ação ou a defesa, de acordo com o artigo 332 do CPC ${ }^{113}$, e também se atribui à presunção a força do meio de prova. Além de quê a figura entre os deve-

\footnotetext{
112 THEODORO JÚNIOR, Humberto. Curso de Direito Processual Civil - Teoria geral do direito processual civil e processo de conhecimento. Vol. I. Rio de Janeiro: Forense, 2012. p. 450.

113 Art. 332.todos os meios legais, bem como os moralmente legítimos, ainda que não especificados neste Código, são hábeis para provar a verdade dos fatos, em que se funda a ação ou a defesa.
} 
res da parte, durante a instrução da causa, é praticar o ato que lhe for determinado pelo juiz, segundo o artigo 340, do Código de Processo Civil ${ }^{114}$.

Caso injustificadamente uma parte deixe de produzir sua prova e esta esteja ao seu alcance, e não justificar a recusa omitirá no cumprimento da ordem judicial, ficará autorizado o uso de seu comportamento como indício de elemento útil ao julgamento da causa. Posto que no âmbito das provas indiciárias, ou, circunstanciais valer-se-á pelo emprego do dinamismo do ônus da prova ${ }^{115}$.

Em audiência preliminar e na sentença que o direito material exigirá a inversão do ônus da prova, mesmo não permitam a formação de convicção de verossimilhança ${ }^{116}$.

Para Luiz Guilherme Marinoni e Sérgio Cruz Arenhart ${ }^{117}$ :

A inversão do ônus da prova, em principio, deve dar a parte que originariamente não possui o ônus da prova, a chance de produzi-la. Nessa lógica, quando se inverte o ônus é preciso supor que aquele que vai assumi-lo terá a possibilidade de cumpri-lo, sob pena de a inversão do ônus da prova significar a imposição de uma perda, e não apenas a transferência de um ônus. A inversão do ônus da prova, nessa linha, somente deve ocorrer quando o réu tem a possibilidade de demonstrar a não existência do fato constitutivo.

Porém no fato de o réu ter condições de provar a não existência do ato/ fato constitutivo, não permite por si só a inversão do ônus da prova. Apenas ocorrerá quando as especificidades da situação de direito material, componente do processo ratificar que não é racional a ultimato do elemento probatório do fato constitutivo, entrementes determinar a prova de que o fato constitutivo não existe, ou seja, a inversão do ônus da prova é forçosa de uso do bom senso quando ao autor for impraticável, ou muito difícil provar o fato constitutivo, mas ao réu mais fácil de provar a sua inexistência. Assim, o juiz terá a avaliação independente de quem foi que a lançou ${ }^{118}$.

Sendo impraticável a produção da prova às duas partes, não há que se arra-

${ }^{114}$ RENHART, Sérgio C., MARINONI, Luiz Guilherme. Comentários ao Código de Processo Civil. $5^{\circ}$ vol. Tomo I. Ed. São Paulo: Revista dos Tribunais, 2000. p. 247.

115 NEVES, Daniel Amorim Assumpção. Manual de Direito Processual Civil. 3. ed. São Paulo: Método. 2011.p. 419.

${ }^{116}$ MONTENEGRO FILHO, Misael. Curso de Direito Processual Civil. 9. ed. São Paulo: Atlas, 2004.p. 452.

117 RENHART, Sérgio C., MARINONI, Luiz Guilherme. Teoria Geral do Processo. 3. ed. rev e atual. - São Paulo: Editora Revista dos Tribunais, 2008. p. 328.

${ }^{118}$ MARINONI, Luiz Guilherme. Formação da convicção e inversão do ônus da prova segundo as peculiaridades do caso concreto. Disponível em:http://jus.com.br/revista/texto/8845/ formacao-da-conviccao-e-inversao-do-onus-da-prova-segundo-as-peculiaridades-do-casoconcreto\#ixzz2Z3tRemu8. Acessado em: 14.07.2013. 
zoar em inversão do ônus da prova em audiência preliminar.

Nesses casos, o julgador não conseguirá aperfeiçoar convicção de verossimilhança, e, portanto, surgirá uma circunstância de se viabilizar o esclarecimento probatório, contudo premissa é saber se tal situação de falta de objetividade deve ser tolerada pelo autor, ou seja, por aquele que tem o ônus de provar. nhart $^{119}$ :

Discorre o exemplo dado por Gerhard Walter apud Luis Marinoni e Are-

A vítima que foi nadar em clube de natação que deixou de informar, seguindo as regras legais, a profundidade das piscinas aptas aqueles que ainda estavam aprendendo a nadar. Ocorrida a morte em piscina de grande profundidade, sem que essa estivesse definida como imprópria aos nadadores iniciantes - mediante placa informativa, como impunha a legislação, os familiares do falecido ingressaram com ação ressarcitória. Os autores afirmaram que a vítima morreu afogada, enquanto o réu disse que a morte teria sido ocasionada por um colapso. Não havia como demonstrar uma coisa nem outra, e assim existia uma situação de "inesclarecibilidade". Diante da impossibilidade de produção de prova, sequer indiciária, o juiz não teve condições de chegar nem mesmo a uma convicção de verossimilhança. Frise-se que, nesse caso, além de ter sido impossível a inversão do ônus da prova na audiência preliminar, o juiz não encontrou uma convicção de verossimilhança.

Sobre a inversão do ônus, e a aplicação da dinâmica das provas tem-se destacar que a relação de consumo. Alternativamente, que a alegação articulada pelo consumidor é verossímil, ou que por ser hipossuficiente merece atenção. A inversão não ofende o principio da isonomia, devendo o juiz se valer quanto ao princípio da fundamentação nos termos do artigo 93, IX, da Constituição Federal ${ }^{120}$. notórios ${ }^{121}$.

Tem-se ainda como forma de exemplo para a dinâmica das provas os fatos

Nesse sentido abrilhanta Moacyr Amaral Santos ${ }^{122}$ :

Com efeito, em cada esfera social, da mais letrada à mais humilde, há uma porção de conhecimentos que, tendo passado por uma experiência

\footnotetext{
${ }^{119}$ ARENHART, Sérgio C., MARINONI, Luiz Guilherme. Teoria Geral do Processo. 3. ed. rev e atual. - São Paulo: Editora Revista dos Tribunais, 2008.

${ }^{120}$ MONTENEGRO FILHO, Misael. Código de processo civil comentado e interpretado. 3 . ed. São Paulo: Atlas. 2013. p. 404.

${ }^{121}$ RENHART, Sérgio C., MARINONI, Luiz Guilherme. Comentários ao Código de Processo Civil. $5^{\circ}$ vol. Tomo I. Ed. São Paulo: Revista dos Tribunais, 2000. p. 211.

${ }^{122}$ SANTOS, Moacyr Amaral. Primeiras linhas de direito Processual Civil. $2^{\circ}$ vol. 22. ed. São Paulo: Saraiva. 2002. p. 343.
} 
contínua e prolongada, ou, quando não, pelo crivo da crítica coletiva, fruto da ciência, da arte, da técnica ou dos fatos cotidianos, faz parte de sua communis opinio. É certo, por outro lado, que essa communis opinio pode variar, conforme o lugar, o tempo, o progresso da ciência ou da técnica, às transformações políticas, sociais, religiosas etc., mas não deixa de ser também certo que as afirmações nela fundadas, pó qualquer esfera social, em que se formou, adquirem autoridade que a afirmação individual não pode ter, porque aquela traz consigo e resulta da crítica e da apuração coletiva.

Assim, diante das experiências vividas em coletividade, a própria sociedade poderá fiscalizar a exatidão dos litigantes e do magistrado. Portanto, é um exemplo de que há regras que podem ser flexibilizada e no presente exemplo, com efeito preconiza o artigo 334, I do CPC, que independem de prova os fatos notórios ${ }^{123}$.

Cândido Rangel Dinamarco ${ }^{124}$ disserta que o "ônus da prova é o encargo, atribuído pela lei a cada uma das partes, de demonstrar a ocorrência dos fatos de seu próprio interesse para as decisões a serem proferidas no processo".

Ao final, de todos os apontamentos descritos tem-se que a dinâmica das provas decorrem dos princípios da igualdade art. $5^{\circ}$, caput, da CF e art. $125, \mathrm{I}, \mathrm{CPC}$, lealdade, boa-fé e veracidade arts. 14,16, 17, 18 e 125, III, do CPC) e do princípio da cooperação com o órgão jurisdicional art. 339, 340, 345 e 355, do Código de Processo Civil) ${ }^{125}$.

Tendo em vista o apresentado verifica-se que a dinâmica do ônus da prova é um meio de se fazer efetivo acesso à justiça, vez na impossibilidade de realizá-la - prova - pela parte que não detém meios para efeivá-la, poderá a parte se valer da inversão do ônus, sob os olhos atentos do magistrado competente, para então sobressair à justiça que tanto se busca nas demandas.

\section{Conclusão}

Diante da necessidade de se submeter muitas vezes ao pleito jurisdicional do Estado juiz, um pretenso demandante se sente vulnerável em obter sua pretensão ouvida e resolvida pelo Estado.

Assim, decorreu a abordagem do tema, com intuito de se valer como parte

\footnotetext{
${ }^{123}$ Nesse sentido: RENHART, Sérgio C., MARINONI, Luiz Guilherme. Comentários ao Código de Processo Civil. $5^{\circ}$ vol. Tomo I. Ed. São Paulo: Revista dos Tribunais, 2000. p. 210. ALVIM, Arruda, ASSIS, Araken e ALVIM, Eduardo Arruda. Comentários ao Código de Processo Civil.Rio de Janeiro: G/Z Editora. 2012. p. 521.

${ }^{124}$ DINAMARCO, Cândido Rangel. Instituições de Direito Processual Civil. Vol. III, 2. ed. Ed. Malheiros. p. 71.

125 DONIZETTI, Elpídio. Curso didático de direito Processual Civil. 15. ed. São Paulo: Atlas. 2011. p. 554.
} 
e demonstrar que nós estudiosos do direito e todo o maquinário governamental têm condições de se valer de todos os princípios mandamentais para acessar a justiça tempestivamente e solucionar de forma lídima tramitação de um processo, com resposta ao social.

Tendo como fulcro que um processo se inicia com a propositura da ação, e se encerra depois de percorrido todo o procedimento processual, com a entrega da prestação jurisdicional invocada, é a marcha processual ditada pelo magistrado que ditará o direito às partes litigantes.

Para fazê-lo de forma a responder o anseio social, em primeiro momento o processo dependerá da cristalina narração dos fatos e a invocação pertinente ao caso, sobretudo diante do bem jurídico que suportou eventual depreciação, moral ou material. Devendo para tanto, deduzir sua pretensão jurídica, adequadamente com a norma que se reputa aplicável.

São norteadas as provas dentro de um aspecto da perspectiva objetiva, ou seja, dentro de uma instrumentalização das afirmações, com o fim de dar conhecimento às partes e ao magistrado, e dentro de uma perspectiva subjetiva em demonstrar ao magistrado a alegação presente, a fim de prestar o conhecimento geral dos adventos pretéritos, assumindo então dentro de uma função dialética e dialógica.

As partes devem se socorrer de todos os meios de prova em direito admitidas, para a finalidade de levar ao magistrado uma conviç̧ão em torno dos mesmos fatos. Vez que o magistrado deverá ponderar a veracidade do quanto alegado nos fatos com o fim de solucionar a lide.

Para instrumentalizar o processo as partes devem se utilizar dos meios legais, dos meios moralmente legítimos, mesmo que não taxados no Código de Processo Civil, desde que hábeis para provar a verdade dos fatos, em que se funda a ação ou a defesa.

Dentre os meios de prova elencados no Código de Processo Civil verificam-se os seguintes: depoimento pessoal, confissão, exibição de documento ou coisa, prova documental, prova testemunhal, prova pericial, inspeção judicial.

Tendo em vista que o Processo Civil ganhou importante vertente rumo autonomia científica, que admitiu a sua abrangência enquanto elemento distinto da relação de direito material. Não se deixou perder de vista a instrumentalidade do processo que, manifesto enquanto relação de direito público tem como finalidade tutelar os bens de direito material.

São bens aqueles tratados e vivenciados pelas partes na vida fática, fora, portanto da esfera do Poder Judiciário. Para ter a veracidade desses fatos são necessárias produções de provas.

Os autos são instrumentalizados a partir de suas narrações e pedidos pelas partes. O juiz, quando se vale do poder instrutório, baseia-se suas limitações impostas pela alegação das partes, devendo se valer apenas dos fatos revelados no processo. 
Ao magistrado que faz cominar seu poder, para empenhar a prova apenas dos fatos que velam e patrocinam uma das partes, equivoca-se gravemente, pois nessa conjunção em ser neutro, embaraça o quadro fático do litígio.

Tão ou mais grave é a atitude de insensibilidade à verdade, quando cabe à abrangência do juiz o meio de desvendá-lo. Ao eleger julgar o litígio, na sombra da imprecisão e fria técnica, decisivamente, pode-se subentender que esse não é um julgador empenhado com os nortes constitucionais do equitativo processo ansiado pelo contemporâneo Estado de Direito.

Finalmente em relação às regras do ônus da prova caso esgote todos os meios de possibilidade para provar um fato, e este não tiver sido aclarado, havendo qualquer outro meio e a outra parte da demanda puder contribuir para a formação do convencimento do juiz, ele deverá determiná-la de oficio, assim é este o sentido que trataremos no item abaixo.

Tendo em vista o apresentado verifica-se que a dinâmica do ônus da prova é um meio de se fazer efetivo acesso à justiça, vez na impossibilidade de realizá-la - prova - pela parte que não detém meios para efetivá-la, poderá a parte se valer da inversão do ônus, sob os olhos atentos do magistrado competente, para então sobressair à justiça que tanto se busca nas demandas.

\section{REFERÊNCIAS:}

ALVIM, Arruda. Manual de Direito Processual Civil. 13. ed. São Paulo: Revista dos Tribunais. 2010.

. ASSIS, Araken e ALVIM, Eduardo Arruda. Comentários ao Código de Processo Civil.Rio de Janeiro: G/Z Editora. 2012.

BEDAQUE, José Roberto dos Santos. Direito e processo: influência do direito material sobre o processo. São Paulo: Malheiros, 1995.

BERMUDES, Sergio. Direito Processual Civil. Estudos e pareceres. $2^{\mathrm{a}}$ série. São Paulo: Saraiva. 1994.

BUENO, Cassio Scarpinella. Curso sistematizado de direito processual civil. Teoria geral do direito processual civil. 4. ed. São Paulo: Saraiva. 2010.

BUENO, José Antonio Pimenta. Apontamentos sobre o Processo Criminal Brasileiro. $3^{\text {a }}$ Ed. Rio de janeiro: H. Ganier, 1959.

CHAGAS, Carlos Eduardo N.. Inspeção judicial. Disponível em: http://caduchagas. blogspot. com.br/2013_01_01_archive.html. Acessado em: 14.07.2013

CÂMARA, Alexandre Freitas. Lições de direito processual civil. 24. ed. São Paulo: Ed. Atlas. 2013.

CASTRO, Ana Paula de. Disponível em: http://www.ambitojuridico.com.br/si- 
te/?n_link=revista_artigos_leitura\&artigo_id=90\%2096. Acessado em: 14.07.2013.

CINTRA, Antonio Carlos de Araújo. GRINOVER, Ada Pellegrini Grinover. DINAMARCO, Cândico R. Teoria Geral do Processo. 9. ed. São Paulo: Malheiros. 1993. Jornal da tarde. Dicionário Brasileiro da Língua Portuguesa. Porto Alegre: Ed. Globo. 1994.

COSTA, Marco Antônio Rebouças da. Considerações Sobre a Prova no Processo Civil. Disponível em: http://jus.com.br/revista/texto/11358/conside racoes-sobre -aprova-no-processo-civil. Acessado em: 11.07.2013.

DINAMARCO, Cândido Rangel. Instituições de Direito Processual Civil. Vol. III, 2. ed. Ed. Malheiros.

DONIZETTI, Elpídio. Curso didático de direito Processual Civil. 15. ed. São Paulo: Atlas. 2011.

FRANCO, Sandra Rose de Mendes Freire e. os limites do poder instrutório do juiz. Disponível em http://www.ambitojuridico.com.br/site/index. php?nlink=revistaartigosleitura\&artigo_id=10885. Acessado em: 14.07.2013.

GRECO, Leonardo. Os atos de disposição processual: primeiras reflexões. Revista Eletrônica de Direito Processual, out./dez. 2007. Disponível em: http://www.e-publicacoes.uerj.br/index.php/quaestioiuris/article/download/3691/2561. Acessado em: 14.07.2013.

GÓIS, Veruska Sayonara de. Os Limites do Poder Instrutório do Magistrado no Processo Civil. Disponível em: http://www.ajuris.org.br/index.php?option $=$ com_content $\& v i e w=$ article $\&$ id $=147$ :os-limites-do-poder-instrutorio-do-magistrado-no-processo-civil\&catid=59: doutrina-nacional\&Itemid=20. Publicado em 06.05.2006. Acessado em: 14.07.2013.

GUSTIN, Miracy Barbosa de Sousa. (RE) pensando a pesquisa jurídica. Belo Horizonte: Del Rey, 2006.

LENZA, Pedro e GONÇALVES, Marcus Vinicius Rios. Direito Processual Civil esquematizado. 3. ed. São Paulo: Saraiva, 2012.

MACHADO, Costa. Código de Processo Civil interpretado e anotado. São Paulo: Manole. 2006.

MACHADO \& MALLMANN. Disponível em: http://machadoemallmann.com.br/ publicacoes?cd=3. Acessado em: 14.07.2013.

MARA, Tânia. Depoimento pessoal. Disponível em: http://www.webestudante. com.br/we/index.php?option=com_content $\&$ view=article \&id=119:depoimentopessoal\&catid=10:processo-civil\&Itemid=85. Acessado em: 13.07.2013. 
MENEZES, Solleon. Provas no Processo de Conhecimento do Processo Civil-Parte Geral. Disponível em: http://solleon.wordpress.com/2008/09/24/provas-no-processo-de-conhecimento-do-processo-civil-parte-geral/. Acessado em: 14.07.2013.

RENHART, Sérgio C., MARINONI, Luiz Guilherme. Comentários ao Código de Processo Civil. 5. vol. Tomo I. Ed. São Paulo: Revista dos Tribunais, 2000.

MONTENEGRO FILHO, Misael. Código de Processo Civil comentado e interpretado. 3. ed. São Paulo: Atlas. 2013.

MONTENEGRO FILHO, Misael. Curso de Direito Processual Civil. 9. ed. São Paulo: Atlas, 2004.

MOREIRA, José Carlos Barbosa. O novo processo civil Brasileiro. 8. ed. Rio de Janeiro: Forense. 2010.

NERY JUNIOR, Nelson e ANDRADE NERY, Rosa Maria de. Código de Processo Civil Comentado e Legislação extravagante. 9. ed. São Paulo: Revista dos Tribunais, 2006.

NEVES, Daniel Amorim Assumpção. Manual de Direito Processual Civil. 3. ed. São Paulo: Método. 2011.

OLIVEIRA, Fernando José Vianna. As Provas no Processo Civil. Disponível em: http://www.conteudojuridico.com.br/artigo, as-provas-no-processo-civil,32434. html. Acessado em: 13.07.2013.

RENHART, Sérgio C., MARINONI, Luiz Guilherme. Comentários ao Código de Processo Civil. 5. vol. Tomo I. Ed. São Paulo: Revista dos Tribunais, 2000.

SANTOS, Moacyr Amaral. Primeiras linhas de direito Processual Civil. 2. vol. 22 Ed. São Paulo: Saraiva. 2002.

SILVA, Ovídio Araújo Baptista da. Curso de Processo Civil. 5. ed. São Paulo: Revista dos Tribunais. 2000.

THEODORO JÚNIOR, Humberto. Curso de Direito Processual Civil - Teoria geral do direito processual civil e processo de conhecimento. Vol. I. Rio de Janeiro: Forense, 2012.

TOURINHO FILHO, Fernando da Costa. Manual de Processo Penal. Ed. Saraiva. 1997.

VÍDERO, Samantha. Teoria Geral da Prova no Direito Processual Civil. Disponível em: http://www.viajus.com.br/viajus.php?pagina=artigos\&id=1507\&idAreaSel= 15\&seeArt=yes . Acessado em: 14.07.2013.

XAVIER, Trícia Navarro. Poderes Instrutórios do Juiz no Processo de Conhecimento. Disponível em: http://www.ccje.ufes.br/direito/posstrictosensumestrado/Links/ 
disser tacaotriciaxavier.pdf. Acessado em: 14.07.2013.

KNIJNIK, Danilo. A prova nos juízos Cível, Penal e Tributário. Rio de Janeiro: Forense. 2007.

KOMMERS, Ezequiel Rodrigo. O Ônus Dinâmico da Prova no Processo Civil Brasileiro. Disponível em:http://bibliodigital.unijui.edu.br:8080/xmlui/bitstream/ handle/ 123456789/1326/TC\%20para\%20entrega.pdf?sequence=1 Acessado em: 14.07.2013. 